and $<0.5(n=51)$. BL or Wk 4 changes in levels of individual analytes were not associated with Wk 24 ACR50 or DAS28-CRP responses.

Conclusions: SIR 50mg q4w + MTX, vs pbo + MTX, inhibited radiographic progression in RA pts in SIRROUND-D and strongly inhibited biomarkers of joint and tissue destruction while enhancing markers of bone formation. These data suggest SIR may actively suppress inflammatory pathways implicated in joint destruction in RA pts.

Disclosure of Interest: B. Dasgupta Employee of: Janssen Research \& Development, LLC, K. Campbell Employee of: Janssen Research \& Development, LLC, A.-C. Bay-Jensen Shareholder of: Nordic Bioscience, Employee of: Nordic Bioscience, M. Karsdal Shareholder of: Nordic Bioscience, Employee of: Nordic Bioscience, K. Sweet Employee of: Janssen Research \& Development, LLC, M. Sims Shareholder of: GlaxoSmithKline, Employee of: GlaxoSmithKline, M. Loza Employee of: Janssen Research \& Development, LLC

DOI: 10.1136/annrheumdis-2017-eular.3588

\section{OP0104 TOCILIZUMAB: DOSE REDUCTION OR INTERVAL SPACING - WHICH PROVES A BETTER TAPERING STRATEGY FOR RHEUMATOID ARTHRITIS IN CLINICAL REMISSION?}

Y. Urata ${ }^{1}$, S. Abe ${ }^{2}$, B. Devers ${ }^{3}$, Y. Nakamura ${ }^{4}$, H. Takemoto $^{5}$, K.-I. Furukawa ${ }^{6}$ ${ }^{1}$ Department of Rheumatology, Tsugaru General Hospital, Gosyogawara;

${ }^{2}$ Marketing Department; ${ }^{3}$ Marketing Department, Diagnostics Division, Sekisui Medical Co., Ltd., Tokyo; ${ }^{4}$ Departments of Orthopaedic Surgery; ${ }^{5}$ Departments of Dermatology, Tsugaru General Hospital, Gosyogawara; ${ }^{6}$ Department of Pharmacology, Hirosaki University Graduate School of Medicine, Hirosaki, Japan

Background: A number of studies have revealed that reduction of biological disease-modifying anti-rheumatic drugs (bDMARDs) is possible for some rheumatoid arthritis (RA) patients in whom bDMARD treatment has induced clinical remission or low disease activity.

For tocilizumab (TCZ), while there have been studies concerning tapering, there have been no studies regarding which tapering option is better in RA after clinical remission has been achieved: a dose reduction strategy (DRS) or an interval spacing strategy (ISS).

We previously demonstrated that a twin target strategy [targeting both a simplified disease activity index (SDAl) score of less than 3.3 and normalization of matrix metalloproteinase (MMP) 3 levels] can achieve effects non-inferior to standard care with regard to maintaining clinical remission in the rT-4study.

Objectives: To evaluate any significant differences that may be present between the two strategies (DRS and ISS) while tapering TCZ in RA patients who satisfied the SDAI remission and MMP-3 normalization targets under the twin target scheme.

Methods: DRS was used in patients treated with intravenous (IV) TCZ, whereas ISS was used for those treated by subcutaneous injection (SC). 57 RA patients who demonstrated SDAI remission and MMP-3 normalization using TCZ (IV, $\mathrm{n}=42$; $\mathrm{SC}, \mathrm{n}=15$ ) participated. Dose reduction methodology (every 3 months): DRS- dose reduced by $80 \mathrm{mg}$; ISS- period between injections increased by one week; up to a minimum dose of: DRS- $80 \mathrm{mg}$ every 4 weeks; ISS-162 mg every 6 weeks. The dose was reverted to the previous level in the event that the target scores were exceeded, and the lower dose was eventually reattempted after the target was re-achieved. The primary outcome was the difference in the number of the times when a patient's SDAl exceeded 3.3 across the four time points.

Results: Fifty-five patients completed the observation period of 12 months and were analyzed (ITT). There were differences in the number of the times which SDAl scores exceed the target over the 12 months in the DRS group vs the ISS group: $2.4 \pm 1.7$ and $0.9 \pm 1.2$, respectively $(p=0.0027)$. DRS had a duration (months) of maintained SDAI remission significantly shorter than that of ISS ( $3.9 \pm 5.0$ vs $7.4 \pm 5.1, p=0.0213$ ). At month 12 , the proportions for DRS and ISS, respectively, for $\Delta$ mTTS $\leq 0.5$ were 71.4 and $66.7 \%(p=0.7293)$; for maintained $\mathrm{HAQDI}=0$ were 83.3 and $66.7(\mathrm{p}=0.4227)$ and for $\mathrm{AE}$ were 81.0 and 46.7 $(p=0.0112)$. The total dose for TCZ in DRS tended to be lower than that for ISS (1367 $\pm 840 \mathrm{vs} 1626 \pm 583 \mathrm{mg}, p=0.0824)$. The rate of total TCZ reduction showed a significant difference between DRS and ISS $(29.3 \pm 15.2 \%$ vs $41.8 \pm 15.0 \%$, $\mathrm{p}=0.0037$ ). Comparing three groups consisting of $400 \mathrm{mg}<, 401<<500 \mathrm{mg}$ and $500 \mathrm{mg}<$ across the DRS with ISS groups, there were significantly greater number of times when SDAl exceeded 3.3 in the DRS vs the ISS group; $2.3 \pm 1.6,2.7 \pm 1.8$ and $2.4 \pm 1.9, p=0.0395$.

Conclusions: ISS using the twin targets as defined by the rT-4 study is an excellent strategy that is both safe and cost-effective for RA patients who are both being treated with $\mathrm{TCZ}$ and have reached said targets.

Disclosure of Interest: None declared

DOI: 10.1136/annrheumdis-2017-eular.2501

\section{OP0105 LONG-TERM SAFETY OF TOCILIZUMAB FROM LARGE CLINICAL TRIAL AND POSTMARKETING POPULATIONS}

S. Mohan, M. Michalska, J. Yourish, J. Pei, S. Gale, C. Birchwood, E. Berber. Genentech, Inc., South San Francisco, CA, United States

Background: Tocilizumab (TCZ) is a recombinant humanized monoclonal antibody targeted against the interleukin- 6 receptor that was approved to treat rheumatoid arthritis (RA) in the EU in 2009 and in the US in 2010. TCZ has now completed long-term extension (LTE) follow-ups in a number of intravenous and subcutaneous RA trials.

Objectives: To provide an updated report on the incidence of safety events during TCZ treatment in patients with RA using data from multiple completed clinical trials and their LTEs, as well as to provide an update from the global TCZ postmarketing safety database.

Methods: Incidence and reporting rates of adverse events (AEs) of special interest, including infections, malignancies, anaphylaxis, bleeding events, myocardial infarctions, gastrointestinal perforations, strokes, hepatic events and demyelination, were estimated from 2 distinct patient data sets. Incidence rates were calculated from 12 completed TCZ RA clinical trials and their LTE periods and are reported as events per 100 patient-years (PY). Reporting rates were also estimated from the global TCZ postmarketing safety database (Oct 2008 to Oct 2015), which includes information from all spontaneously reported cases and non-interventional programs as well as literature cases, and are reported as cases per 100 patients.

Results: The clinical trial all-exposure population consisted of 7647 TCZ-treated patients with RA (81.6\% female; mean [SD] age, 52 [12.6] years), constituting $22,394 \mathrm{PY}$ (mean follow-up, 2.93 years) of exposure. The overall rate $(95 \% \mathrm{Cl})$ of serious AEs in the clinical trial population was 14.16 (13.67-14.66) per 100 PY. Overall incidence rates for individual events for the clinical trial population are reported in the Table and were consistent in each 6-month period over the 5 -year duration. The global postmarketing population included 606,937 patients. The overall spontaneous reporting rate (range) of AEs of special interest in the postmarketing population was 9.37 (7.35-10.56) cases per 100 patients. Reporting rates of individual safety events of interest in the global postmarketing population are shown in the Table and were consistent in each 6-month period over the 7-year duration.

Table. Adverse Events Across 12 RA Clinical Trials and the Global Postmarketing Safety Database in Patients Who Received TCZ

\begin{tabular}{|c|c|c|c|c|}
\hline \multirow[b]{2}{*}{$\begin{array}{l}\text { Adverse Event of } \\
\text { Special Interest }\end{array}$} & \multicolumn{2}{|c|}{$\begin{array}{l}\text { RA Clinical Trial All-Exposure } \\
\text { Population } \\
\text { (N =7647; 22,394 PY) }\end{array}$} & \multicolumn{2}{|c|}{$\begin{array}{l}\text { Global Postmarketing Safety } \\
\text { Database Population* } \\
\text { (N=606,937) }\end{array}$} \\
\hline & $\begin{array}{l}\text { Patients } \\
\text { With } \\
\geq 1 \mathrm{AE}, \mathrm{n}(\%)\end{array}$ & $\begin{array}{c}\text { Incidence Rate } \\
(95 \% \mathrm{Cl}), \\
\text { Events/100 PY }\end{array}$ & Cases, $\mathrm{n}$ & $\begin{array}{l}\text { Reporting Rate } \\
\text { (range), } \\
\text { Cases/100 Pts }\end{array}$ \\
\hline Serious infections & $730(9.5)$ & $\begin{array}{c}4.29 \\
(4.02-4.57) \\
\end{array}$ & 17,350 & $\begin{array}{c}2.86 \\
(2.11-3.62) \\
\end{array}$ \\
\hline Malignanciest & $242(3.2)$ & $\begin{array}{c}1.18 \\
(1.05-1.33) \\
\end{array}$ & 1560 & $\begin{array}{c}0.26 \\
(0.18-0.51)\end{array}$ \\
\hline $\begin{array}{l}\text { Injection site } \\
\text { reactions }\end{array}$ & $444(5.8)$ & $\begin{array}{c}6.51 \\
(6.18-6.85)\end{array}$ & NA & NA \\
\hline $\begin{array}{l}\text { Strokes/cerebrova } \\
\text { scular disorders }\end{array}$ & $130(1.7)$ & $\begin{array}{c}0.67 \\
(0.56-0.78)\end{array}$ & 2069 & $\begin{array}{c}0.34 \\
(0.22-0.94)\end{array}$ \\
\hline $\begin{array}{l}\text { Serious bleeding } \\
\text { events }\end{array}$ & $89(1.2)$ & $\begin{array}{c}0.43 \\
(0.35-0.52)\end{array}$ & $2440 \neq$ & $\begin{array}{c}0.40^{\mp} \\
(0.28-0.76)\end{array}$ \\
\hline $\begin{array}{l}\text { Myocardial } \\
\text { infarction }\end{array}$ & $72(0.9)$ & $\begin{array}{c}0.33 \\
(0.26-0.42)\end{array}$ & 1946 & $\begin{array}{c}0.32 \\
(0.21-0.88)\end{array}$ \\
\hline $\begin{array}{l}\text { Gastrointestinal } \\
\text { perforationst }\end{array}$ & $39(0.5)$ & $\begin{array}{c}0.20 \\
(0.15-0.27)\end{array}$ & 632 & $\begin{array}{c}0.10 \\
(0.06-0.30)\end{array}$ \\
\hline $\begin{array}{l}\text { Serious } \\
\text { hypersensitivity } \\
\text { reactions }{ }^{5}\end{array}$ & $56(0.7)$ & $\begin{array}{c}0.26 \\
(0.20-0.33)\end{array}$ & NA & NA \\
\hline Anaphylaxis & $21(0.3)$ & $\begin{array}{c}0.09 \\
(0.06-0.14)\end{array}$ & 1222 & $\begin{array}{c}0.20 \\
(0.09-0.38) \\
\end{array}$ \\
\hline $\begin{array}{l}\text { Serious hepatic } \\
\text { events }\end{array}$ & $9(0.1)$ & $\begin{array}{c}0.04 \\
(0.02-0.08)\end{array}$ & $3567 \neq$ & $\begin{array}{c}0.59 \neq \\
(0.34-1.21)\end{array}$ \\
\hline Demyelination & $8(0.1)$ & $\begin{array}{c}0.04 \\
(0.02-0.07)\end{array}$ & 66 & $\begin{array}{c}0.01 \\
(0.00-0.02)\end{array}$ \\
\hline
\end{tabular}

arthritis; TCZ tocilizumab.

arthritis; TCZ, tocilizumab

Data are for multiple indications and from several sources (spontaneous reports, noninterventional programs, literature cases) reported following market authorization. $\uparrow$ Events of malignancies and gastrointestinal perforations were medically confirmed * Includes both serious and non-serious cases.

$\checkmark$ Serious hypersensitivity was defined as a serious adverse event occurring during or within 24 hours of the injection or infusion, excluding injection site reactions, and not judged unrelated to study treatment by the investigator.

Conclusions: The safety profile of TCZ in the current analysis, which includes information about safety events from 12 clinical trials and their LTEs and across 7 years of real-world postmarketing reports encompassing $\approx 600,000$ patients, was consistent with previous safety reports. These findings are consistent with the previously reported profile of TCZ and indicate that there is no evidence of increased safety risk with increasing exposure to TCZ.

Acknowledgements: This study was funded by F. Hoffmann-La Roche/Genentech, Inc.

Disclosure of Interest: S. Mohan Employee of: Genentech, Inc., M. Michalska Employee of: Genentech, Inc., J. Yourish Employee of: Genentech, Inc., J. Pei Employee of: Genentech, Inc., S. Gale Employee of: Genentech, Inc., C. Birchwood Employee of: Genentech, Inc., E. Berber Employee of: Genentech, Inc.

DOI: 10.1136/annrheumdis-2017-eular.3573 